\title{
SOBRE OS MITOS CONTEMPORÂNEOS
}

Furio Jesi

O mito é uma "história real", ocorrida no tempo das origens, que explica como nasceram todas as coisas do universo e como fizeram os homens, pela primeira vez, para comer, para se reproduzir, para fabricar objetos, para combater, etc. O mito fornece, portanto, ao homem "primitivo" ou "antigo" certos modelos de comportamento sempre válidos. Tudo já aconteceu pelo menos uma vez: para se comportar convenientemente em cada circunstância, é necessário saber como agiu o antepassado mítico na mesma circunstância, e imitá-lo. Por isso, o comportamento das sociedades "primitivas" é com frequência rigorosamente conservador: toda mudança, toda derrogação à tradição, é um absurdo ou um grave risco. As novidades objetivas (por exemplo, a chegada do cargueiro) são reconduzidas e bloqueadas nos esquemas tradicionais do mito (o cargueiro, de fato, torna-se uma embarcação mítica da prosperidade, como aquela do progenitor, etc.).

Na linguagem moderna, a palavra "mito" significa quase sempre "história não verdadeira" ou, pelo menos, "não totalmente verdadeira". O homem possui outros instrumentos (ciência) e outras formas organizativas, com as quais enfrenta os riscos daquilo que não conhece e com as quais forma, às vezes, um modelo de comportamento.

No entanto, da psique dos homens continuam a florescer espontaneamente mitos; e outros mitos são produzidos deliberadamente, para servir a determinados objetivos. Muito frequentemente os novos mitos (ou melhor, as sobrevivências modernas dos antigos mitos) representam uma fuga das restrições e das dores da realidade histórica. Não podendo ser um "herói", o homem cria heróis exemplares nas pessoas que gozam de particular riqueza, sucesso, notoriedade, etc. Não podendo possuir "tesouros" reais, o homem cria tesouros supremos em bens de consumo dos quais ele ressalta sua im-

Sui miti contemporanei.

Riga, Milano, n. 31 (Org. Marco Belpoliti e Enrico Manera), p. 126-128, 2010.

Texto inédito, presente em arquivo privado, escrito em 1971.

Tradução de Davi Pessoa Carneiro 
portância e seu prestígio artificial. Não podendo viver numa comunidade efetivamente solidária, o homem cria comunidades míticas (das "sociedades secretas" das crianças àquelas dos adultos, dos grupos de torcedores esportivos às "comunidades" hippies, etc.). A produção desses mitos está condicionada por uma série de elementos psicológicos, sociais, econômicos, etc., e é apenas compreensível se se confrontam em profundidade os novos mitos com os mitos antigos: se, por trás do mito aparentemente novo, se consegue descobrir o mito antigo, mesmo alterado ou invertido.

O quadro dos principais mitos de uma época permite traçar um diagnóstico clínico da sociedade (os mitos são geralmente, no mundo moderno, valores substitutivos: compensações de valores ausentes ou não percebidos). Ao mesmo tempo, esse quadro permite também avançar alguma hipótese sobre a sociedade sucessiva. Os mitos podem revelar, de fato, as necessidades ainda ocultas e as potencialidades latentes de um grupo humano, e de tal modo constituir um primeiríssimo sintoma revelador da direção que tomarão as transformações do grupo. Precisamente por isso que, às vezes, as imagens míticas de uma época se tornaram clamorosamente as "verdades" científicas, técnicas, sociais, da época sucessiva.

Os mitos, enfim, podem ser usados (e são usados!) para exercer uma verdadeira e peculiar hipnose sobre grupos sociais inteiros, para impor determinadas escolhas (políticas, consumistas, religiosas, etc.). Também nesses casos, a análise do mito é especialmente reveladora, pois permite superar a fachada do mito "tecnicista" ou reconhecer as modalidades e os objetivos de seu uso.

\section{Esquema de sumário}

1. Uma primeira definição do conceito de mito. O homem "primitivo" ou "antigo" que se fecha no mito como um escafandro, antes de mergulhar na realidade. $\mathrm{O}$ totem (isto é, o mastro totêmico) dos índios da América: uma narrativa mítica, esculpido e colocado em meio ao vilarejo, que explica como nasceram e como são feitos o universo e os homens. A mitologia como "manual" que prevê todas as circunstâncias importantes da existência e explica como se deve comportar nelas.

2. Nascimento de um mito novo numa população "primitiva": o mito do cargueiro. Como a mitologia se adequa às circunstâncias. A mitologia está presente também na sociedade moderna. Por quê? Como? 
3. Necessidade de ampliação do espaço. I) Viagens no "grandíssimo" (as peregrinações de São Brandão e as grandes viagens de exploração - a façanha dos Argonautas - a astronáutica). II) Viagens no "infinitamente pequeno" e no "primordial" ("precedentes" míticos da física atômica: o mito gnóstico da luz-matéria, a descida às origens da vida, os mitos ligados ao número 4 e as quatro valências do carbono - o mundo do ínfimo, como cópia em miniatura do mundo do grandíssimo). III) Viagens da "alma" (a experiência do grandíssimo e do pequeníssimo - os casos de Gulliver e de Alice - a "viagem" alucinatória da droga - a descida aos Infernos - o mundo "invertido" de Through the Looking-Glass).

4. Do "mundo invertido" à "festa" em que se suspendem o tempo e os automatismos corriqueiros: necessidade de ampliação do tempo ("festa" e "tempo livre" - a festa mítica grega - a música, a dança: Dioniso, populações "primitivas", o mito da música libertadora - música underground o espetáculo teatral (que evoca ou cria mitos) como "festa" coletiva - o Living Theatre - o mito do ator e da atriz).

5. Do mito do ator/atriz, ao mito do "herói” em geral: ampliação do eu (o herói "positivo" e "negativo" - herói negro —, e a mulher mítica, na antiguidade, junto aos "primitivos", e hoje - o "Trickster", o mago - o ocultismo, o ocultismo tecnicista (Batman) - duas alternativas do herói mítico atual o mito do líder autocrata e o mito do herói benéfico e pacífico (como Gandhi ou Schweitzer) - uma alternativa ao herói fortemente personalizado (agressivo ou pacífico): o herói-símbolo, o campeão esportivo, o cantor, etc. - o herói como aquele que tem sucesso).

6. Mitos da coletividade: ampliação das estruturas sociais (o herói-símbolo, como emblema da sociedade do bem-estar - a Atlântida e as outras sociedades perfeitas do mito antigo - os mitos modernos das perfeitas sociedades futuras - uma alternativa: a recusa das verdades oferecidas pela ciência moderna e instrumentalizadas nas atuais estruturas sociais: o mito como recusa do sistema, a contestação dos jovens — os mitos das "comunidades" hippies - um paralelo antigo: mitos de iniciação, grupos restritos e vinculados por um mito a ser repetido - mitos da cavalaria medieval ontem e hoje, a busca pelo Oriente; a alternativa "de direita": fundações míticas provenientes do Estado - a tripartição mítica das sociedades indoeuropeias (G. Dumézil: soberania sagrada/guerra/produção).

7. Mitos da produção e do consumo: ampliação da atividade e dos bens (mitos 
sobre as origens da metalurgia ou dos trabalhos artesanais em geral - 0 mito moderno do homem que "produz" - sua tecnicização - o valor da coisa produzida - o "tesouro" dos mitos antigos e o moderno bem de consumo que dá prestígio - técnicas de "persuasão" que se servem de elementos míticos - condicionamento das escolhas de massa; mitos antigos e "primitivos" relativos à sabedoria e ao conhecimento - mitos modernos ligados à cibernética e à automação (como conclusão do "mito da máquina") - do mito alquímico do homunculus de Paracelso e do mito cabalístico do Golem ao mito do homem não-homem, o robô).

Para a iconografia da publicação poderiam ser úteis os seguintes tipos de documentos, para serem colocados ao lado uns dos outros ou alternados continuamente no contexto:

1. documentos iconográficos relativos a mitos antigos e "primitivos";

2. imagens de como os "modernos" representaram os equivalentes das grandes figuras míticas: por exemplo, La belle dame sans merci (no Romantismo, na Arte Nouveau, na Pop Arte), paisagens, "tesouros", do mito. Fotografias de espetáculos teatrais especialmente significativas para ilustrar os mitos do momento;

3. imagens de "involuntária" eficácia "mitológica": formas assumidas pelo poder político, pela vida dos personagens de destaque, etc. Material kitsch;

4. imagens de deliberada eficácia mitológica: material de "persuasão" de todas as proveniências possíveis. 